\title{
KAS GOOGLE ON ÜHE- VÕI KAHESILBILINE SÕNA?
}

\author{
HEIKI-JAAN KAALEP
}

O ma raamatus „Eesti keele foneetika I” küsib Arvo Eek: „Mis on silp?”, ja mainib hiljem, et „seniajani ei leidu silbi defineerimiseks ühtseid foneetilis-fonoloogilisi kriteeriume" (Eek 2008: 47-48). Olukord on veider, sest selliseid eesti keele põhiteemasid nagu välted ja sõnamuutmise reeglid on tavaks käsitleda just silpide kaudu, st millegi sellise kaudu, mida ei osata määratleda. Käesoleva artikli eesmärk on pakkuda lisaks häälduspõhisele käsitlusele võimalust heita pilk eesti silbisüsteemile sellisena, nagu see paistab sõnamuutmises kasutusel olevat. Keelekasutajad tõlgendavad hääldustunnuseid morfoloogia ehk sõnamuutmissüsteemi alusena - kõnelejate ettekujutus sellest, kuidas sõna silbitada, on nende jaoks üks tegureid, mis määrab sõna käänamisviisi valiku - ja seega võib tehtud käänamisviisi otsuste alusel, mida tagantjärele näeme, saada ettekujutuse otsuste aluseks olnud keeleomasest silbitamisviisist.

\section{Eelteadmiste kontroll: kas taba-tüüpi sõnade $t$-lõpuline ainsuse osastav levib või taandub?}

Enne häälduse ja käänamise seoste juurde asumist tuleb selgeks teha esmapilgul kõrvaline seik, mis on seotud ettekujutusega eesti keele arenemise suunast, sest see avaldab otsest mõju sellele, millise hoiakuga lähenetakse käänamises ilmnevatele nähtustele.

Selleks vaatleme I-vältelisi kahesilbilisi vokaallõpulisi ehk C*VCV struktuuriga sõnu. Neid peetakse problemaatiliseks sõnarühmaks: „Millegipärast käänatakse peret asemel osastavas pere, aga isa ja ema asemel vastuoksa isat ja emat” (Künstler 2014). Külli Habichti sõnul „...toimib pesa-tüübi sõnade ainsuse osastava käände vormides... tendents: osastavat käänet markeeritakse $t$-lõpuga... [---] Kolme grammatilise käände (nimetava, omastava ja osastava) vormihomonüümia selles muuttüübis ja markeerimata osastava probleemne eristuvus loovad soodsa pinna osastava kui enamikus muuttüüpides markeeritud käändevormi $t$-lõpuliseks kasutuseks, nt vormid *kõvat, *isat, *emat, *vanat" (Habicht 2006: 18-19).

Oluline on siin see, et $t$-lõpulist osastavat arvatakse just levivat, mitte taanduvat. Kas selline arvamus on aga põhjendatud? Varasemate keelekirjelduste ning eri perioodide keelekasutuse võrdlemine viitab sellele, et $t$-lõpuline osastav hoopis taandub, mitte ei levi.

$t$-lõpuline osastav ei ole uus, vaid vana nähtus. F. J. Wiedemann (1875: 369) on läänemurdeliste osastava vormidena esitanud mitmed sellised, mis tänapäeval pole enam kindlasti võimalikud: ninat, tädit, samat, rajat, nimet, suvet. Johannes Aavik agiteeris $t$-lõpuliste vormide, nagu vanat ja igat, vas- 
tu, seejuures märkides vastava malli esinemist nii murde- kui ka kirjakeeles (Aavik 1912).

Ainsuse nimetava, omastava ja osastava esinemisjuhtumite arvuline vahekord TÜ morfoloogiliselt ühestatud tekstikorpuse aja- ja ilukirjanduse osas on 3:2:1. ${ }^{1}$ TÜ kirjakeele korpuse vanemast osast (1890-ndate, 1900-ndate ja 1910-ndate aja- ja ilukirjanduse korpustest ning Asutava Kogu protokollidest 1919-1920, kokku 3 miljonit sõna) ${ }^{2}$ ilmneb, et tabelis 1 esitatud problemaatiliste sõnade $t$-lõpuliste vormide suhted lõputa vormidega (viimased sisaldavad summeerituna nii ainsuse nimetava, omastava kui ka osastava) on vahemikus 1/50 kuni 1/250. Arvud näitavad selgelt, et lõputa osastav oli juba siis palju populaarsem kui $t$-lõpuline: iga $t$-lõpulise vormi kohta pidi tulema 7 kuni 40 lõputa osastava vormi. Tabelis 1 on ka samade sõnade vormide suhted XXI sajandi esimese kümnendi internetikeeles, nagu seda kajastab eestikeelsete veebilehtede korpus etTenTen mahuga 270 miljonit sõna (päringud tehti www. keeleveeb.ee kaudu).

Tabel 1.

\section{$t$-lõpulise ainsuse osastava suhe lõputa vormidesse}

\begin{tabular}{|l|c|c|c|c|c|c|}
\hline & isat/isa & emat/ema & kõvat/kõva & vanat/vana & vabat/vaba & kenat/kena \\
\hline $\begin{array}{l}\text { Kirjakeel } \\
1890-1920\end{array}$ & $1 / 100$ & $1 / 100$ & $1 / 50$ & $1 / 250$ & $1 / 200$ & $1 / 100$ \\
\hline $\begin{array}{l}\text { Netikeel } \\
2013\end{array}$ & $1 / 1000$ & $1 / 2000$ & $1 / 250$ & $1 / 550$ & $1 / 300$ & $1 / 300$ \\
\hline
\end{tabular}

Tabeli 1 andmete pealiskaudsest võrdlusest on näha, et $t$-lõpuliste vormide suhteline sagedus võrreldes lõputa vormidega on 100 aasta jooksul vähenenud. Kõigil tabeli sõnadel oli $t$-lõpulisi vorme etTenTeni korpuses vähemalt 30, seega on tegemist üsna sagedaste sõnadega, mis hoiavad oma varasemast ajast pärit käänamisviisi päris hästi alles. Lisaks neile oli rohkem kui $15 t$-lõpulist vormi järgmistel küllaltki hilistel võõr- või laensõnadel, mille $t$-lõpuliste ja lõputa vormide suhted olid: sumot/sumo 1/10, minit/mini 1/20, logot/logo 1/100, gurut/guru 1/20, sojat/soja 1/10, egot/ego 1/30, homot/homo 1/100, demot/demo $1 / 20$. Vaid sõnadel judot/judo $1 / 5$ ja galat/gala $1 / 5$ on lõputa osastav pigem suureks erandiks (selle põhjuseks võib olla mh see, et hääldus on vastavalt $d \check{z} u u d o$ ja gaala). Ei ole märgata taba-tüüpi sõnade üleminekut $t$-lõpulisele a. os-le, vaid vastupidist tendentsi: sedamööda, kuidas võõrsõna eesti keeles kohaneb, omandab see $t$-lõpulise osastava asemel lõputa vormi.

$t$-lõpulise osastava leviku mulje võib olla tingitud asjaolust, et kirjalikus vormis kättesaadava eestikeelse materjali hulk, sealhulgas toimetamata tekstide hulk, on tänapäeval palju suurem kui varem. Kui tekstikorpus on suurem, siis on seal ka taba-tüüpi sõnade $t$-lõpulisi osastava vorme absoluutarvuna rohkem, kuigi selliste vormide suhteline osakaal on hoopis vähenenud.

\footnotetext{
${ }^{1} \mathrm{http}: / /$ www.cl.ut.ee/korpused/morfkorpus/ (16. XII 2015).

${ }^{2} \mathrm{http}: / /$ www.cl.ut.ee/korpused/baaskorpus/ (16. XII 2015).
} 
Taba-tüüpi sõnade puhul on näha, et käänamissüsteemi korrapära suureneb: sõnad nihkuvad tüüpidesse, kuhu nad oma algvormi häälikulise kuju põhjal peaksidki kuuluma. Samas tähendab see, et eesti morfoloogilise süsteemi loomulik areng toob kaasa mõistmist raskendava vormihomonüümia. Et sellega toime tulla, peab ilmselt arenema mõni morfoloogiaväline, nt süntaktiline kompensatsioonimehhanism, nagu sõnajärje järjest rangem reeglistumine vms.

\section{Mis on silp?}

Inimkõne on häälikute järjend. Häälikuid üksteise järel kuuldavale tuues teevad kõneorganid jadamisi liigutusi, mille jooksul kõnetrakti suurem avatus vaheldub väiksema avatuse või suletusega. Sellist kõnetrakti avatuse vaheldumist kirjeldatakse kui silpide vaheldumist: need häälikud, mille puhul on avatus kõige suurem, on silbi tuumad, ja need häälikud, mille puhul kõige väiksem, silpide vahekohad ehk silbipiiride asukohad. Kõne jaotumine silpideks kui hääldusüksusteks on kõnelejatele ja kuulajatele kergesti tajutav ja intuitiivselt mõistetav. Esimesed suulise kõne ülesmärkimise häälduspärased kirjasüsteemid olid nimelt silbipõhised.

Mitmeid lingvistilisi seaduspärasusi, sealhulgas ka eesti sõnamuutmisreegleid ning välteid, on traditsiooniliselt kirjeldatud silpide teatud tunnuseid abiks võttes. Silpidel on sisemine struktuur: silbi algus ja silbiriim, mis omakorda jaguneb tuumaks ja koodaks. Tuum on silbi ainus kohustuslik osa. Ta on kõige helilisem osa silbiriimist, tavaliselt vokaal(ide järjend). Algus ja kooda koosnevad konsonantidest.

Silbipiiride täpse asukoha määramiseks, st kahe silbi tuumade vaheliste häälikute jagamiseks eelmise silbi kooda ja järgmise silbi alguse vahel on välja pakutud mitmesuguseid eeskirju, kuid alati klausliga, et kõigi keelte silbitamisreeglid ei pruugi olla ühesugused. Näiteks võib tuua eeskirja, mis tugineb sonoorsuse ehk helilisuse põhimõttele (vt Morelli 1999: 7-8), st häälikuid võib järjestada sonoorsuse skaalal: vokaalid on kõige helilisemad, sulghäälikud kõige vähem helilised; häälikute järjendis suureneb helilisus silbi tuuma suunas liikudes ning silpide vahekoht on seal, kus helilisus on väikseim, täpsemalt vähima helilisusega hääliku ees, nt ka-la, kors-ten. Teiseks võib esitada eeskirja, mille aluseks on väide, et sõna keskel oleva silbi alguses ei saa olla sellist häälikujärjendit, mida selles keeles ühegi sõna algussilbis ei ole. Näiteks kuigi vähima helilisuse reegli kohaselt oleks õige silbitada ma-gma, siis kuna gma ei ole ühegi eestikeelse sõna alguseks, siis tuleks silbitada mag-ma.

Eesti keele grammatikates kasutatav silbipiiride määramise eeskiri koosneb järgmisest kahest reeglist (1):

1. Silbi tuumaks on alati vokaal (EKG: 111); „Silbi kohustuslikuks osaks on vokaalne silbituum, st silpi peab ikka jääma mõni täishäälik (mõnes keeles, nagu näiteks tšehhi keel, saab ka liikvida esineda silbituumana: vlk 'hunt', trg 'turg')" (Hint 1998: 106-107).

2. Vokaalidevahelisest konsonantjärjendist alustab järgmist silpi viimane konsonant (EKG: 111).

EKG märkus esitab ka ühe alternatiivse võimaluse (mida EKG küll ise ei järgi): „Juhtude korral, kus vokaalidevahelise konsonantjärjendi lõpus on 
lühike klusiil + sonorant, on mõne uurija järgi silbipiir eesti keeles klusiili ees, seega siis ma-gma, tu-bli, e-lek-tri" (EKG: 111).

Ka Mati Hint (1998: 107, 108) esitab võimalike silbitamisnäidetena sõnad eks-tra-le, in(t)-te-graal, vints-kle-ma, põhjendades oma näidete õigsust väitega, et silbi lõpus peaksid olema samad häälikud, mis võivad esineda sõna lõpus, ja silbi alguses samad mis sõna alguses.

Hindi põhjenduseks toodud reegel on liiga piirav; see sobib tema toodud näidetega, aga ei saa olla üldkehtiv. Kui uskuda Hinti, siis sõna magma ei oleks eestlasel üldse võimalik silbitada: pannes silbipiiri ma-gma, saaksime sõna alguseks sobimatu gma; aga pannes silbipiiri mag-ma, saaksime sõna lõpuks sobimatu silbi mag.

Kuid tähtis on siinkohal hoopis see, et Hint juhib tähelepanu sellele, et eesti keele silbitamine ei pruugi olla nii lihtsate reeglitega kirjeldatav nagu EKG-s või „Eesti keele käsiraamatu” ortograafiapeatükis (EKK 2007: 58-59) esitatakse.

\section{Käänamine tugineb hääldustunnustele}

Sõna käänamisviisi sõltuvust sõna häälikulisest kujust (ehk morfoloogilise tüübi sõltuvust fonoloogilistest tunnustest) saab mõnel juhul kasutada selleks, et kindlaks teha, kuidas tõlgendavad või tajuvad keele kõnelejad sõna fonoloogilist struktuuri.

Eesti keele kui sõnamuutmissüsteemi omava keele olemuslikuks tunnuseks on sõnavara jagunemine eri moel käänatavatesse-pööratavatesse gruppidesse - muutkondadesse - vastavalt sõnade häälikulisele ja tuletislikule iseloomule. Selle poolest sarnaneb eesti keel soome, saksa ja vene keelega, kuid erineb näiteks ainult üht käändkonda omavast türgi keelest, milles ühetaolisele käänamisviisile lisanduvad ainult morfofonoloogiliselt tingitud vokaalharmoonia ja mõned fonoloogilised vaheldused (Wurzel 1987: 62). Sõnade jagunemine muutkondadeks esindab iseenesest üsna lihtsat mentaalset protsessi: kui sõnal on häälikuliste või muude tunnuste komplekt $x$, siis käänamisviisiks on $A$, kui aga komplekt $y$, siis $B$. Näiteks kui käändsõna lõpeb kaashäälikuga ja rõhk pole eelviimasel silbil, siis lõpuvokaaliks on $i$ ja osastav on ilma lõputa, näiteks steel : steeli : steeli, president $:$ presidendi : presidenti, seminar : seminari : seminari. (Kui sõnal ongi ainult üks silp, siis loomulikult pole tal rõhk eelviimasel silbil (Kaalep 2012: 435, 436).) Kui aga lihtsõna lõpeb kaashäälikuga ja rõhk on justnimelt eelviimasel silbil, siis lõpuvokaali valikul tuleb arvestada lõpuhäälikuid detailsemalt (vaikimisi on lõpuvokaaliks $i$, kuid nt in-lõpulistel $a$ : visin : visina, ik-lõpulistel $u$ : triibik : triibiku) ja osastava lõpuks on $t$, nt indeks : indeksi : indeksit, iisop : iisopi : iisopit, kartul : kartuli: kartulit (Kaalep 2012: 435, 436). Samade reeglite alusel käänatakse ka võõrnimesid kahel eri moel, nt Tusk : Tuski : Tuski ja Donald : Donaldi : Donaldit.

Täpsuse huvides tuleb lisada, et sõna häälikulisele ja tuletuslikule kujule tuginevad liigitusreeglid kõlbavad keele kasutaja poolt vaadatult tarvitamiseks muidugi ainult sel juhul, kui tal varasemast pole teada, et sõna muudetakse mingil erandlikul moel. Näiteks meel ja keel tüvevokaaliks on $e$ ning osastava lõpuks $t$ : keel : keele : keelt, kuigi nad sarnanevad ülaltoodud näitesõnaga steel. Selliseid erandlikke, oma välisele kujule mittevastavalt muudeta- 
vaid sõnu on keeles vähe ning nende eri vormid on suure kasutussagedusega; ainult selle tõttu on võimalik, et keele kasutajad nende erandlikkust mäletavad.

Eesti keeles on käänamisviisi määravateks tunnusteks „lõpuhäälikud, rõhu olemasolu eelviimasel silbil, viimase silbi pikkus ja teatud juhtudel ka eelviimase silbi pikkus" (Kaalep 2012: 424). See tähendab, et sõna struktuuri (mis määrab käänamisviisi) üle otsustamiseks peab määrama sõna silbid ja arvutama nende pikkused.

\section{Probleem: silbitamise ja käänamise mittevastavus}

1. On päris mitmeid võõrnimesid, mis on eesti silbi traditsioonilise määratluse järgi ühesilbilised: Google [gu:gl], Kindle [kindl], Haydn [haidn], Strömpl, Lendl, Pjotr (nagu Tusk), kuid mille ainuvõimalik käänamisviis järgib kahesilbiliste malli: armastan keda? - Google'it, Kindle'it, Haydnit, Strömplit, Lendlit, Pjotrit (nagu Donaldit); mitte kuidagi ei saa osastav olla ilma $t$-ta: armastan *Google'i, *Kindle'i, *Haydni, *Strömpli, *Lendli, *Pjotri, *Donaldi.

2. On mitmeid kahesilbilisi II-vältelisi, ratsu-tüüpi sõnu, mille osastavas kasutatakse oodatava $t$-lõpu (ratsut) kõrval paralleelselt ka ilma lõputa vormi: (seda) rubla, vedru, tubli, käbla, tibla, mobla, vobla, sebra, vibra, lebra, säbru, adru, mügri (kasutusandmed on pärit korpusest etTenTen). Selline tendents on varemgi teada, nii et mõned osastava lõputa vormid, nt rubla, vedru, tubli, on ka ÕS-i järgi lubatud. See tähendab, et ülaltoodud sõnade käändevormi valikul liigitavad mõned keelekasutajad nad samasse gruppi kahesilbiliste Ivälteliste sõnadega, nagu taba. Taba-tüüpi I-välteliste sõnade silbistruktuuri iseloomustab teatavasti asjaolu, et esimene silp on lühike, st sõna on struktuuriga $\mathrm{C}^{*} \mathrm{~V}-\mathrm{CV}$. Ülaltoodud sõnad on eesti keele traditsioonilise silbitamisreegli kohaselt aga struktuuriga $\mathrm{C}^{*} \mathrm{VC}-\mathrm{CV}$.

Kuidas seletada seda, et teatud sõnade käänamisviisi valikul ignoreerivad keelekasutajad tunnust - silbistruktuuri -, mida nad teiste sõnade puhul järgivad? Kui tegemist oleks vanade, paljukasutatavate sõnadega, siis võiks oletada, et nende erandlik käänamisviis pärineb minevikust ning on lihtsalt meie ajani säilinud. Aga nende sõnade ühiseks tunnuseks ei ole see, et nad on vanad või paljukasutatavad, vastupidi, mitmed on pigem uued ja/või vähekasutatavad.

\section{Lahendus: silbitamisreeglite revideerimine}

Esimene võimalik lahendus oleks ühesilbiliste sõnade puhul väita, et tegelikult nad ei olegi ühesilbilised, vaid nendele lisatakse švaa ehk toimuvad „konsonantühendi lihtsustused", nagu sõnades ansambl $\rightarrow$ ansambel, šedöövr $\rightarrow$ šedööver (Hint 1998: 192). Selline seletus oleks sobilik kahel tingimusel: 1) kui ilma švaad lisamata oleks üldse võimatu neid sõnu välja öelda või 2) kui lõputa osastav oleks mingigi hääldamise korral võimalik. Kumbki ei vasta tegelikkusele: hoolikalt švaad vältiv hääldus on võimalik, aga lõputa osastav on ka sellisel juhul võimatu. Olukord on samasugune nagu saksa keeles, kus helilisele häälikule eelnevat švaad võib, aga ei pea hääldama, kuigi saksa ortograafias on ta $e$-tähena alati esindatud (Wiese 1986: 697-698). 
Lahenduseks oleks seletus, et keelekasutajad ikkagi järgivad silbistruktuuri, aga kumbki eesti keele silbitamisreegli põhimõte (1) tegelikult ei kehti. See tähendab, et silbi tuumaks ei pea tingimata olema täishäälik ning vokaalidevahelisest konsonantjärjendist ei alusta järgmist silpi alati viimane konsonant. Küll aga kehtib põhimõte, et eesti keeles järgitakse silbitamisel sonoorsuse astmeid.

Tasub tähele panna, et kõigil eespool toodud problemaatilistel sõnadel esineb sõnas häälikujärjend sulghäälik + heliline häälik, antud näidetes isegi valdavalt liikvida: $l$ või $r$. Sonoorsusjärjestuse põhimõtte kohaselt peaks silbipiir olema kõige helitumas kohas, sulghääliku kui kõige helituma ees. Sel juhul tuleb välja, et nn ühesilbiliste sõnade õige silbitamine oleks: $g u u$-gl, kin-dl, ström-pl, len-dl, hai-dn, pjo-tr, st silbi tuumaks võib eesti keeles olla ka heliline konsonant, just nagu tšehhi või saksa keeleski (Wiese 1996: 35).

Samuti tuleb välja, et ülaltoodud kahesilbiliste vokaallõpuliste sõnade silbitamisvariant oleks: ru-bla, ve-dru, tu-bli, kä-bla, ti-bla, mo-bla, vo-bla, se-bra, vi-bra, le-bra, sä-bru, a-dru, mü-gri. See tähendab, et nende sõnade silbistruktuur on $\mathrm{C} * \mathrm{~V}-\mathrm{CCV}$ ehk lühike lahtine silp + lühike lahtine silp, mille vokaaliks pole $e(t a+b a)$; silbi tuuma ees olevate kaashäälikute hulk teatavasti ei mõjuta silbi pikkust/raskust, seega teise silbi struktuur CCV on ekvivalentne CV-ga.

Kokkuvõtteks: kui postuleerida, et eesti keeles võib silbi tuumaks olla heliline konsonant, siis sõnade nagu [guugl] ja Strömpl käänamisviis on sõna silbistruktuuriga kooskõlas, sõltumata isegi sellest, kus täpselt on silbipiir, kas sulghääliku ees või järel. Kui postuleerida veel see, et silbipiir võib (paljude keelekasutajate arvates) olla vähima sonoorsusega hääliku ees, siis sõnade nagu kä-bla ja mü-gri lõputa osastav on kooskõlas vormi valiku reegliga, mille tingimuseks on, et kahesilbiline vokaallõpuline (kusjuures lõpuvokaaliks pole e) sõna oleks lühikese esisilbiga, st taba-tüüpi.

\section{Kas muid seletusi ei ole?}

Olles näidanud, et eesti silbistruktuuri määrava eeskirja teistsugune käsitlus võimaldab seletada teatud sõnade muidu seletamatut käänamisviisi, tuleb kontrollida, kas seda seletamatut käitumist ei saaks seletada hoopis mingi muu mõjuri kui sõna hääldustunnuste (mille esindajaks silbistruktuur ju on) olemasolu kaudu.

Nimelt on tähtis kindlaks teha, kas sõna hääldamisviis või õigemini see, kuidas eestlane sõna hääldamisviisi tõlgendab, st millised on seal tema arvates käänamise jaoks olulised tunnused, on tõesti see ainus asi, mis antud näidete käänamisviisi valikut juhib. Kui see on ainus, siis saab käänamisviisi alusel teha järeldusi hääldamisviisi ja/või -tunnuste äratundmise kohta. Kui see aga pole ainus viis, st kui nende sõnade käänamist mõjutab veel miski peale fonoloogiliste tunnuste, siis ei saa nende käänamisviisi võtta selleks aluseks, millest saaks tuvastada eestlase jaoks olulisi sõna häälduslikke tunnuseid ja nende väärtusi.

Sisuliselt tuleb vastata potentsiaalsele väitele, et „eesti keele käänamine on nii keeruline, seda mõjutavad tegurid nii tundmatud, et selle põhjal ei saa midagi väita". 
Väide sonoorsusjärjestuse eranditeta kehtimisest ka eesti keeles tugines esiteks ühesilbiliste konsonantlõpuliste ning teiseks $\mathrm{C} * \mathrm{VCCV}$ struktuuriga sõnade (kusjuures sõnasisene konsonantühend koosneb sulghääliku ja $l$ või $r$ järjendist ning lõpuvokaaliks pole $e$ ) käänamisele. Et viimaste hulk on nii väike ning et neid kõiki kasutatakse osastavas nii lõputa kui ka $t$-lõpulise vormina, siis nende lähem uurimine väite - teatud sõnade käänamisviisi ei mõjuta miski muu peale häälikulise struktuuri - range tõestamise eesmärgil ei tundu perspektiivikas. Seega jäävad vaatluse alla vaid ühesilbilised konsonantlõpulised sõnad.

Väite kontrollimiseks tuleb üle vaadata kõik sellised konsonantlõpulised sõnarühmad, mille osastav võib keeletaju põhjal olla $t$-lõpuline, ent mis silbitamise traditsioonilise eeskirja kohaselt on ühesilbilised. On vaja näidata, et antud juhtumeil on algvormi häälikulistele tunnustele mittevastav $t$-lõpp seletatav mingi konkreetse erandliku teguriga, mis pole ülekantav teistele samasuguse struktuuriga sõnadele, ning seetõttu ei lükka nad ümber väidet, et käänamine tugineb tavaliselt silbistruktuurile.

Keeletaju avaldumist võime empiiriliselt jälgida nii sõnastike kui ka tegeliku kasutuse kaudu. Keelematerjali allikana kasutame sõnastikke ja tekstikorpusi: viimast normingut (ÕS 2013), vanemaid sõnastikke (Wiedemann 1869; ÕS 1918; VÕS 1936; VÕS 1953; ÕS 1960) ning TÜ koondkorpust ja etTenTen korpust.

ÕS 2013 ja VVS sõnaloendis on käesoleval juhul huvipakkuva struktuuri ning käänamisviisiga 112 sõna. Nad jagunevad järgmistesse rühmadesse.

1. Vanad ja erandlikud sõnad, mille praegune käänamisviis on tekkinud sel moel, et varasema käänamisviisi olemus on (vähemalt osaliselt) säilinud, ainult sõnavormide häälikuline kuju on muutunud.

1.1. Leksikaliseerunud ja lühenenud tuletised (9 sõna): juba Wiedemannil (1869) esinevad juus, käis, laos, päis, teos (Wiedemannil teus : teukse : teust), veis (Wiedemanni järgi vedis : vedikse : vedist, millest sai veis : veikse : veist kaudu nüüdne veis : veise : veist); küps (Wiedemannil küps a. os. küpse, kuid TÜ koondkorpuse 1890-ndate korpuses esinevad nimetava vormidena nii küps kui ka küpse; a. os. küpset), aus (Wiedemannil auus); jaos on ÕS 1960 järgi aj. 'jaosmaa'.

1.2. Varem ainsuse nimetava kahesilbilised, nüüd aga lõpukao tõttu ühesilbilised sõnad (õel, mõis) ja kõik sõnad, mis moodustavad 13. ja 14. käändkonna (tüüpsõnad suur ja uus), vastavalt 28 ja 20 sõna. Näiteks varasemast varsi : varren : vartta on nüüdseks saanud vars : varre : vart.

2. Tuletised.

2.1. Paradigmaatilise derivatsiooni liide $-v$ (11 sõna), nt saav $:$ saava $:$ saavat.

2.2. nd-tuletised eend, koond, loend, soend, toend, tõend, vaond, vöönd; ng-tuletised laeng, loeng, seong, soeng, toeng; rd-tuletis soerd; ts-tuletised peats, päits; $k$-tuletis veok (VÕS 1953); s-tuletised seos (ÕS 1918), veos (VÕS 1936).

3. Uudissõnad.

Toes ja eos (VÕS 1936) on uudissõnad; uudissõna käänamisviisi määrab sõna looja/väljapakkuja, kes ei pruugi järgida keeles sel hetkel kehtivaid produktiivseid sõnamuutmismalle. 
4. Problemaatiline norming kõrb.

VÕS 1953 alates on norminguks kõrb : kõrbe : kõrbet, varasem norming sama tähendusega sõnale oli kõrb : kõrve : kõrbe. etTenTeni andmetel on praegugi levinuimaks käänamisviisiks ühesilbilistele omane lõputa osastav: kõrb : kõrbe : kõrbe, st ÕS-i norming ei vasta keeletajule. Sellisel juhul ei saa normingulist käänamisviisi õieti kasutada argumendina, kui arutelu all on keeletajule vastavate reeglite olemus.

5. Kahe erineva vokaali järjendit sisaldavad, tegelikult kahesilbilisena, rõhuga esimesel silbil, hääldatavad sõnad: kaos (ká-os; esineb juba ÕS 1918), prior (prí-or), stoik (stó-ik), kiosk (kí-osk). Seejuures sõna kiosk käänamine sõltub sellest, kas rõhk on $i$ või $o$ peal (viimasel juhul võib häälduseks olla ka [kjosk]). Mõlemale mallile vastavat käänamisviisi võib kohata nii XIX sajandi alguse ajalehtedes kui ka tänapäeval: kiósk : kióski : kióski, mitm. os. kióske või kíosk : kíoski : kíoskit, mitm. os. kíoskeid.

6. Kreml, pärl, žanr - sonoorsusskaala ennustaks, et silbitamine võiks olla ka krem-l, pär-l, žan-r. etTenTenis leidubki neist sõnadest nii $t$-lõpulist kui ka lõputa osastavat, mis on kooskõlas oletusega, et nende sõnade silbitamise üle otsustamisel ei ole keelekasutajad järjekindlad või ühel meelel.

Ülaltoodud jaotus on mõneti tinglik, sest mõningaid sõnu võiks paigutada ka teisiti. Nt kui tuletis on küllalt vana, leksikaliseerunud ja praegu sagedasti kasutatav, siis võiks tema praegust käänamisviisi seletada pigem traditsioon kui tuletislik iseloom. St 2. grupi sõnu võiks liigitada hoopis 1. gruppi. Või kui tuletatud sõnas on vokaaljärjend $e o$ või $a o$, siis võib kahtlustada, et see tundub eestlasele kahe silbi tuuma järjendina, mitte diftongina, ning käänamist seletab sel juhul sõna häälikuline, mitte tuletislik struktuur. St 2. grupi sõnu võiks liigitada hoopis 5. gruppi.

Omaette problemaatiline rühm on sk-liite abil moodustatud slaavi asulanimed (Tsehhanovitš 2007), millel on rõhk viimasel silbil ja mille osastav peaks seega olema lõputa, kuid on alati $t$-lõpuline, nt Novorossiisk, Podolsk, Omsk, Tomsk, Minsk, Smolensk, Kursk, Krasnojarsk, Novosibirsk. (Samas Poola linna Gdansk osastav on etTenTenis kaks korda kujul Gdanski ja kaks korda Gdanskit.)

Võrdluseks on oluline märkida, et muudel häälduslikult sarnastel juhtudel, st kui ühesilbilise sõna lõpus on järjend heliline konsonant $+s+t$ või $p$, esinesid etTenTenis ainult lõputa osastava vormid: hõlsti, Holsti, pulsti, kunsti, Ernsti, inspi (Osa inspi tuleb kindlalt isiklikust rahutusest), pürsti, vürsti jpt. Mõtteeksperimendina: ka Taani firma Maersk ainuvõimalik osastava vorm oleks Maerski.

Eesti keele kõnelejad tunduvad järgivat reeglit, et kui asulanimi lõpeb $s k$-ga, siis osastav on $t$-lõpuline. See tähendab, et sõna eripärane käänamisviis on antud juhul tingitud ainuüksi talle omasest erilisest semantilisest omadusest, mitte sellest, et ta esindaks mingit üldist senitundmatut häälikulist või võõrapärasuse aspekti, mis silpide arvu asemel määraks sõna käänamisviisi.

Selle osa kokkuvõtteks võib öelda, et ei ilmnenud midagi, mis lükkaks ümber väite, et [guugl]-tüüpi sõnade $t$-lõpulise osastava põhjuseks on sõna tajumine kahesilbilisena. 


\section{Ader ja põder}

Ader ja põder esindavad 18-sõnalist rühma (ÕS 2013), mille eristavaks tunnuseks on asjaolu, et ehkki nad on kahesilbilised kaashäälikuga lõppevad sõnad, käänatakse neid sama malli järgi nagu ühesilbilisi kaashäälikuga lõppevaid sõnu. See tähendab, et olukord on täpselt vastupidine kui ülaltoodud [guugl]tüüpi sõnade puhul: näib, et algvormi silpide arv kas ei mõjuta käänamist üldse, või ei saa silbi tuumaks pidada mitte ainult $l$ ega $r$, vaid isegi sulghääliku ja sõnalõpulise helilise kaashääliku vahel olevat täishäälikut, švaataolist $e$-d.

Tänapäeval esindab ader üht mitteproduktiivset kahesilbiliste sõnade käänamismalli, st kuulub suletud muuttüüpi; produktiivset malli esindab vader: vaderi : vaderit. Sõnadele ader ja põder kohalduvat käänamismalli ei saa tuletada nende häälikulisest kujust, vaid see tuleb eraldi ära õppida, kusjuures lisaks astmevahelduslikkusele tuleb meelde jätta, et tüvevokaaliks on produktiivse vokaali $i$ asemel $a, e$ (koger : kogre) või $u$ (puder : pudru). Teisisõnu, aderrühma sõnade algvormi silpide arv tõepoolest ei mõjuta käänamisviisi valikut.

Praeguse sõnamuutmissüsteemi seisukohalt imelikku sõnarühma seletab keeleajalugu: varasema käänamisalgoritmi (vahe)etapid on (vähemalt osaliselt) säilinud, kuid sõnavormide häälikuline kuju muutunud. Omal ajal olid need 18 sõna kahesilbilised ja lõppesid täishäälikuga, kuuludes oma häälikulise ehituse poolest samasse gruppi sõnaga mets; vrd soome metsä : metsän : metsää. Häälikumuutuste käigus teisenes atra : atran : atraa Wiedemanni sõnastikus (1869) oleva adr : adra : atra kaudu praegusele kujule ader : adra : atra. (Eduard Ahrensi (2003: 133) järgi hääldati neid XIX sajandi algupoolel ilma sõnasisese $e$-ta, kuigi varasemates sõnastikes esitati koos $e$-ga.) Seejuures paneme tähele, et ühevokaalilisest sõnast, mille sõnalõpulises kaashäälikuühendis võiks täheldada sonoorsuse kasvu (nt atr, mets, kahv, latv), on švaa või $e$ lisamisega saanud kahesilbiline ainult sellisel juhul, kui sõna lõpus oli sulghääliku järel heliline kaashäälik $l$ või $r$ (vigel, teder jt), st kui häälikute sonoorsuste vahe oli küllalt suur. Ehkki eesti keele loomulikule suundumusele vastav hääldusviisi muutumine ei ole nende 18 sõna puhul veel kaasa toonud käänamisviisi muutust, võib ennustada, et kui mõne sõna kasutussagedus tulevikus piisavalt väheneb, muutub ka tema käänamine. Juba toimunud muutumise näidetena võib tuua Wiedemanni sõnastikus (1869) olnud nigl : nigla: nikla ja nagl : nagla : nakla (tähenduses 'nael'), mis tänapäeval on nigel : nigela : nigelat ja naagel : naagli : naaglit (tähendus 'pulk puittarindis').

Ader-rühma sõnadel esineb ainsuse omastava vormis sõnasisene lühikese sulghäälikuga algav konsonantjärjend, osastava vormis on see sulghäälik aga geminaadina, nõrga ja tugeva astme vaheldust võib kirjeldada kui vältevaheldust (sõna häälikuline koosseis ei muutu): adra : atra. Kui silbitamiseeskiri erineb traditsioonilisest, siis muutub ka selle rühma sõnade tüvemuutuse kirjeldus ja ta pole enam nii sarnane nõrgeneva vältevahelduse üldise mustriga. ${ }^{3}$ Kui silbitada traditsioonikohaselt $a d-r a$, siis selle kui nõrgaastmelise vormi ja tugevaastmelise vormi at-tra (või att-ra?) erinevus seisneb selles, et esisilbi lõpp pikeneb. Tüvemuutuse mehhanism on lihtne ja läbipaistev. Kui silbitada aga käesolevas artiklis pakutava põhimõtte kohaselt $a$-dra, siis tugevaastmelise vormi saamiseks peab teise silbi algushäälik „minema” osaliselt esimese

\footnotetext{
${ }^{3}$ Probleemile juhtis tähelepanu artikli anonüümne retsensent.
} 
silbi lõppu ning nõrgaastmeline vorm ei ole II, vaid I vältes, mis ei vasta nõrgeneva vältevahelduse üldreeglile. Tüvemuutuse mehhanism on seega keerulisem ja erandlik. Vaatame mõlemat probleemi - esisilbi häälikulise koosseisu püsivus ja omastava vormi välde - eraldi.

Esisilbi häälikulise koosseisu püsivus ei ole tegelikult väga tugev nõue. Nõrgenev vältevaheldus on eesti keeles produktiivne nähtus, millele alluvad ühesilbilised konsonandilõpulised sõnad, nt plats : platsi : platsi, part : pardi : parti, bard : bardi : bara $\bar{d} i$. Seejuures on näha, et teise silbi alguse konsonant võib muutuda ka esisilbi lõpuks ja võtta oma kanda III välte väljendamise (par-di : part-ti), ehkki ei pruugi (bar-di : barr-di). Ader-rühma puhul näeme, et ei käesolevas artiklis pakutav silbitamisviis $a$-dra ega ka traditsiooniline ad-ra rikuks seda üsna vähepiiravat esisilbi häälikulise koosseisu reeglit: a-dra /ad-ra : at-tra.

Kui lugeda ühesilbilised sõnad III-vältelisteks, siis nõrgeneva vältevahelduse vormide mall oleks 3:2:3 (part : pardi : parti). Kui silbitada ad-ra, saaksime tema vältevahelduse malliks 1:2:3 (a-der : ad-ra : at-tra), kui silbitada $a$-dra, saaksime malliks 1:1:3 (a-der : a-dra : at-tra). Kumbki mall ei ole reeglipärasega päris vastavuses. See ei ole ka üllatav, sest selle rühma sõnadega on toimunud häälikumuutused, mida paljude teiste konsonantühendit sisaldavate, algselt kahesilbiliste vokaallõpulistega ei toimunud. Oma erandliku ajaloo poolest sarnanevad nad laadivahelduslike sõnadega, mille vormidega toimunud häälikumuutuste tagajärjel näeme nende väldete vaheldumisi väga mitmesugustes kombinatsioonides, nt 1:1:3 (rohi : rohu : rohtu, rehi : rehe : rehte), 1:3:1 (lugu : loo : lugu), 3:1:3 (õlg : óla : õlga). Siinkohal peakski küsima: millel õigupoolest põhineb oletus, et ader-rühma sõnade omastava vormi välde on üldse oluline?

Vältevahelduse reeglipärane mall 3:2:3 on osa eeskirjast, mis võimaldab uutest ja tundmatutest sõnadest moodustada õigeid käändevorme. Ükski ülaltoodud laadivahelduse mall ega ader-rühma sõnade vältevahelduse mall seda ei võimalda. Uusi kahesilbilisi kaashäälikulõpulisi esmavältelisi sõnu ei käänata astmevaheldusliku malli järgi, mida ader esindab, ja keelereeglite omandamise või rakendamise seisukohalt on ükskõik, kuidas sõna ader omastava vormi seejuures silbitatakse või mis välde talle omistatakse.

Kas on teada mõni muu nähtus, mõni keelefakt, mille ilmnemist seletaks just asjaolu, et ader-rühma sõnade omastav on II vältes, mistõttu tema silbitamine peaks olema $a d$-ra? Teadaolevalt sellist nähtust pole; ainsaks argumendiks traditsioonilise silbitamiseeskirja poolt on, et „siis 18 ader-rühma sõna ainsuse omastav on (meie keelekirjelduses) paljude muude sõnade ainsuse omastava taoline". Sellist tüüpi argumenti ei saa pidada selliseks, mis silbitamise põhimõtteid võiks mõjutada. Oleks küll ahvatlev pidada iga märgatud sarnasust tähenduslikuks, kuid keele kui areneva ja muutuva süsteemi puhul võib mõni nähtav seaduspärasus olla tingitud ka asjaolude juhuslikust kokkusattumisest. Ader-rühma sõnadel on selleks juhuslikuks asjaoluks nende kasutussagedus, mille tõttu on kuni tänapäevani säilinud kivinenud käänamisviis, mis algvormi häälikulisele kujule enam ei vasta. Püüe kirjeldada erandlikke sõnu nii, et nad kuuluksid reeglipõhistega kokku - antud juhul väites, et ka erandsõna nõrga astme vorm ei saa olla muus kui II vältes -, ei pruugi teha kirjeldust tervikuna selgemaks. 
Selle osa kokkuvõtteks võib vist öelda, et ader-rühma sõnad sobivad hästi illustreerima eesti keeles toimunud arengut, kuid tänapäeva käänamissüsteemiga nad vastavuses ei ole, mistõttu selle süsteemi toimimise (ja tema aluseks oleva silbitamise) kirjeldamisel ei ole hädavajalik nendega arvestada.

\section{Lõpetuseks}

Üldised teoreetilised kaalutlused, mida käesolevas töös järgiti, olid järgmised: sõnu käänatakse üsna reeglipäraselt, lähtudes algvormi (ainsuse nimetava) häälikulis-tuletislikust kujust ning eesti keele morfoloogiat valitsevad reeglid on muuttüübikesksed. Tööhüpoteesiks oli, et eesti keele käänamissüsteem ei ole oma olemuselt väga keeruline; kui mõni osa temast paistab ebaloogiline, siis võib selle taga kahtlustada kirjeldaja- või uurijapoolset valetõlgendust. Valetõlgenduste üheks tõenäoliseks põhjuseks on omakorda probleemid algandmetega ehk sellega, mida peetakse faktideks.

Teooria peaks olema faktidega kooskõlas. Keeleteaduses on faktideks keeles täheldatavad tõsiasjad, näiteks silpide arv sõnas või käändelõpuks valitava afiksi vorm. Kui ettekujutus eesti keele faktide osas erineb sellest, mis tegelikus keeles toimub, siis ei ole lootagi, et jõutakse tegelikkusega kooskõlas oleva teooriani. Seetõttu on faktide ülekontrollimine äärmiselt oluline, isegi kui pole kohe otseselt näha, millist teoreetilist seisukohta see mõjutab. Käesoleva artikli teemaks olidki mõned eesti keele faktid, mis lähemal vaatlemisel ei osutu mitte nii kindlaks, kui varem on arvatud. Kui jälgida keelekasutajate käitumist, siis silbi tuumaks võib eesti keeles pidada mitte ainult vokaali, vaid ka helilist konsonanti ning sõnasisese silbi alguseks võib ehk pidada mitte ainult üksikut konsonanti, vaid ka klusiiliga algavat konsonantjärjendit.

Artikli valmimist on toetanud Euroopa Regionaalarengufond Eesti Arvutiteaduse Tippkeskuse kaudu, Haridus-ja Teadusministeeriumi uurimistoetus IUT20-56 „Eesti keele arvutimudelid” ning Norra ja Euroopa Majanduspiirkonna finantsmehhanismide teaduskoostöötoetus EMP160 „Saami-Eesti keeletehnoloogiaalane koostöö: sarnased keeled, ühesugune tehnoloogia”.

\section{Kirjandus}

A avik, Johannes 1912. Väiksed keelelised märkused. - Päewaleht 10. IX, nr 209, http://dea.digar.ee/cgi-bin/dea?a=d\&d=paevalehtew19120910.2.3 (17. VI 2015).

Ahrens, Eduard 2003. Uue ajastu misjonilingvist: Eduard Ahrens 200 (koguteos). Koost ja toim Kristiina Ross. Eesti Keele Instituut. Tallinn: Eesti Keele Sihtasutus.

Eek, Arvo 2008. Eesti keele foneetika I. Tallinn: Tallinna Tehnikaülikooli Kirjastus.

EKG = Mati Erelt, Reet Kasik, Helle Metslang, Henno Rajandi, Kristiina Ross, Henn Saari, Kaja Tael, Silvi Vare, Eesti keele grammatika I. Morfoloogia. Sõnamoodustus. Tallinn: Eesti Teaduste Akadeemia Eesti Keele Instituut, 1995.

EKK = Mati Erelt, Tiiu Erelt, Kristiina Ross, Eesti keele käsiraamat. Kolmas, täiendatud trükk. Tallinn: Eesti Keele Sihtasutus, 2007. 
H a bi c ht, Külli 2006. Meie muutuv kirjakeel. - Oma keel, nr 1, lk 12-19.

Hint, Mati 1998. Häälikutest sõnadeni. Eesti keele häälikusüsteem üldkeeleteaduslikul taustal. Teine, ümbertöötatud trükk. Tallinn: AS Pakett.

Ka a le p, Heiki-Jaan 2012. Käänamissüsteemi seaduspärasused. - Keel ja Kirjandus, nr 6, lk 418-449.

Künstle r, Aili 2014. Oi, kas see on enam eesti keel? - Sirp 7. XI 2014, http:// www.sirp.ee/s1-artiklid/varamu/oi-kas-see-on-enam-eesti-keel (17. VI 2015).

Morelli, Frida 1999. The Phonotactics and Phonology of Obstruent Clusters in Optimality Theory. PhD. University of Maryland (College Park, Md.). http:// dx.doi.org/doi:10.7282/T37W6B13 (17. VI 2015).

Tsehhanovitš $2007=$ М. А. Цеханович, Суффикс -ск- в русской топонимии и проблема наложения морфем в оттопонимических прилагательных. - Доклад на XLII научной студенческой конференции по топонимике, 21.03.2007. Русское географическое общество, Московский центр, Топонимическая комиссия http://rgo.msk.ru/commissions/toponymy/stc42/05.html (17. VI 2015)

VVS = Ülle Viks, Väike vormisõnastik. 1: Sissejuhatus ja grammatika; 2: Sõnastik \& lisad. Eesti Teaduste Akadeemia Keele ja Kirjanduse Instituut. Tallinn, 1992. VÕS 1936 = Elmar Muuk. Väike õigekeelsus-sõnaraamat. 5. trükk. Tartu: Eesti kirjanike selts.

VÕS 1953 = Väike õigekeelsussõnaraamat. Tallinn: Eesti Riiklik Kirjastus.

Wi e d e m a n n, Ferdinand Johann 1869. Ehstnisch-deutsches Wörterbuch. Eestisaksa sõnaraamat. Neljas, muutmata trükk teisest, Jakob Hurda redigeeritud väljaandest. Tallinn: Valgus, 1973.

W i e d e m a n n, Ferdinand Johann 1875. Grammatik der Ehstnischen Sprache. St. Petersbourg.

Wi e s e, Richard 1986. Schwa and the structure of words in German. - Linguistics. An Interdisciplinary Journal of the Language Sciences, kd 24, nr 4, lk 697-724.

Wi e s e, Richard 1996. The Phonology of German. New York: OUP.

W u r z e l, Wolfgang Ullrich 1987. System-dependent morphological naturalness in inflection. - Leitmotifs in Natural Morphology. (Studies in Language Companion Series 10.) Toim Wolfgang U. Dressler, Willi Mayerthaler, Oswald Panagl, W. U. Wurzel. Amsterdam-Philadelphia: John Benjamins Publishing Company, lk 59-95.

ÕS 1918 = ÕSi lätted. Õigekeelsussõnaraamatud läbi sajandi. Eesti keele õigekirjutuse-sõnaraamat 1918. [Faksiimile.] Tallinn: Eesti Keele Sihtasutus, 2007. ÕS 1960 = Õigekeelsuse sõnaraamat. Toim E. Nurm, E. Raiet, M. Kindlam. Eesti NSV Teaduste Akadeemia Keele ja Kirjanduse Instituut. Tallinn: Eesti Riiklik Kirjastus.

ÕS 2013 = Eesti õigekeelsussõnaraamat ÕS 2013. Toim Maire Raadik. Tallinn: Eesti Keele Sihtasutus. 


\section{Is Google a mono- or disyllabic word in Estonian?}

Keywords: Estonian, syllabification, declension

The article addresses Estonian syllabification as reflected in practical word inflection. According to the traditional view the nucleus of an Estonian syllable is invariably a vowel, while the next syllable begins with the last consonant of an intervocalic consonant sequence. There are, however, some foreign names like Google [gu:gl], for example, which despite being monosyllabic in terms of the traditional definition of the Estonian syllable can only be declined like a two-syllable consonant-final word, e.g. PartSg Google'it. In addition there are several disyllabic words of the second quantity degree, i.e. nouns of the $\mathrm{C}^{*} \mathrm{VC}-\mathrm{CV}$ structure like ratsu 'steed', where in parallel with the expected PartSg ending - $t$ (ratsut) a zero-ending form is used, as if the word had a C*VCCV structure (like taba 'padlock'), e.g. PartSg käbla 'sl. a fall', mobla 'sl. mobile phone', sebra 'zebra', mügri 'water vole'.

The article calls for a revision of the current rule of Estonian syllabification, arguing that Estonian syllabification practice is similar to the German one, where the syllable nucleus need not always be a vowel as the function can also be fulfilled by a voiced consonant, and it is not only a single consonant, but possibly also a stop-initial consonant sequence that can be considered as the onset of a non-initial syllable.

The arguments are supported by the available information on the declension of the relevant words in practical usage, some since the $19^{\text {th }}$ century. The underlying logic of our approach is that language users tend to base their morphology or word inflection on phonetic facts. Their idea of how a word should be syllabified is one of the factors determining their choice of the declension of the word and thus those choices may a posteriori reveal the underlying language-specific syllabification rules.

Heiki-Jaan Kaalep (b. 1962), PhD, University of Tartu, Senior Researcher, HeikiJaan.Kaalep@ut.ee 